\title{
Studies in Otidea (Pezizales)
}

\author{
HARRI HARMAJA
}

HARMAJA, H. 2009: Studies in Otidea (Pezizales). - Karstenia 48: 33-48. Helsinki. ISSN 0453-3402.

\begin{abstract}
Three new species of Otidea (Pers.) Bonord. (Pyronemataceae, Pezizales) are described on the basis of Finnish material: Otidea angusta Harmaja, Otidea caeruleopruinosa Harmaja, and Otidea flavidobrunneola Harmaja. They were found in rich woods with more or less calcareous soils in SW Finland. A synopsis with an annotated list of the twenty species of Otidea in Finland is presented, four of the latter as nomina provisoria. The habitat of each species is described more accurately than previously. Two keys are presented, one based on macroscopic and habitat characters, the other on microscopic characters. The characters of the North American O. unicisa (Peck) Harmaja are discussed, the species is retained in the genus in spite of its ornamented spores, and it is reported as new to North Carolina. Two previously unreported responses of the pigment in the outer part of the apothecial excipulum to Melzer's reagent are reported. The original material of C. H. Persoon's species referable to Otidea has been revised: no changes in current nomenclature are needed. $O$. cantharella (Fr.) Quél. is considered to be an older name for $O$. caligata (Nyl.) Sacc.
\end{abstract}

Key words: Ascomycetes, endoconidia, Finland, habitat, Melzer's reagent, nomenclature, North America, Persoon, Pezizomycetes, taxonomy

Harri Harmaja, Botanical Museum, Finnish Museum of Natural History, P.O. Box 7, FI-00014 University of Helsinki, Finland; e-mail: harri.harmaja@helsinki.fi

\section{Introduction}

Especially in the 1970's extensive field work was carried out by me in all parts of Finland, especially collecting Otidea. Microscopic studies were carried out, too. The results were only published partially (Harmaja 1974a, 1974b, 1974c, 1976 and 1986). Additional results are published in the present contribution.

The colours of the fresh apothecia are described according to Maerz and Paul (1950). The microscopic characters were studied and measured from dried apothecia in Melzer's reagent. The spore characters have been studied from truly mature - hyaline and preferably discharged - spores. Some studies were also made in boiled cotton blue mounts. The bioclimatic zones are given according to Ahti et al. (1968).
In a synopsis of the Finnish species of Otidea, all species now known from the country are listed. The habitat and distribution of each species are summarized and other notes, e.g. on nomenclature, may be given. The information derived from the Otidea specimens, examined at least macroscopically, of the most important Finnish herbaria has been incorporated into the synopsis (however, newer collections have only been partially seen).

C. H. Persoon (1761-1836) is an important author in the Otidea nomenclature as he described nine species under Peziza that later have generally been considered as species of Otidea. As far as I know, none of them have been typified though some original material does exist in the Nationaal Herbarium Nederland (L) in Leiden, the Netherlands. In 1976, I studied this Otidea 
material of the Herbarium Persoon. The results are published here in short. In addition, an old Friesian specific name of Otidea is rehabilitated.

\section{Notes on specific nomenclature}

\subsection{Identification of Otidea specimens of Her- barium Persoon (L)}

Seven of the nine species that were described by Persoon in different papers under the generic name Peziza and that later have been considered to belong to Otidea are represented in Herbarium Persoon: P. abietina Pers. : Fr., P. alutacea Pers., P. bufonia Pers. : Fr., P. concinna Pers. : Fr., $P$. felina Pers., $P$. grandis Pers., and $P$. umbrina Pers. Twelve specimens are concerned. Materials identified as $P$. austica Pers. or P. onotica Pers. : Fr. did not exist.

The epithets and other information are obviously written in Persoon's handwriting. However, it is to be emphasized that an assignment of specimens as types should be made with utmost care because - as with many old herbaria - it is often difficult or impossible to tell whether the material was available to Persoon prior to the description of the respective species. In fact, I did not make any formal typifications. However, weighted together with the respective protologues, some conclusions from the specimens were made.

Below, the twelve specimens are listed: firstly the name(s) and possible additional text related to the specimen are given, then the numbering of the Nationaal Herbarium Nederland (L) in brackets, and lastly my identification.

Peziza abietina Germania (910.256-1821) $=O$. bufonia

\section{P. abietina? $(910.261-196)=$ O. propinquata}

Verisim. $P$. ab. $\beta$ grandis aut $P$. concinna $(910.261-157)=O$. onotica

P. alutacea $(910.261-12)=O$. bufonia

P. alutacea (910.261-13) $=O$. cf. alutacea (spores fairly large)
P. bufonia Vincennes $1816(911.81-97)=O$. bufonia

P. concinna / vesiculosa ... P. citrina Vincennes $(910.256-1328)=$ O. concinna

P. felina $(910.256-815)=$ O. alutacea

P. umbrina $(910.256-1321)=$ O. bufonia

P. umbrina $(910.261-801)=O$. bufonia

P. umbrina $(910.261-807)=$ Peziza sp. (spores warty)

P. umbrina $(910.261-809)=$ O. bufonia

Conclusions: ( $i$ ) The current use in Otidea of the specific epithets alutacea, bufonia, concinna and onotica can be continued. (ii) Peziza abietina has been used in several senses in the literature and should thus be considered as a nomen confusum, even though the specimen L 910.256-1821 that may belong to true type material represents $O$. bufonia. This identification is at variance with that of Nannfeldt (1966) who stated the specimen to represent a rough-spored member of $P e$ ziza (apparently he confused this specimen with specimen L 910.261-807; see above). The species that is fairly often called O. abietina (Pers. : Fr.) Fuckel especially in the older literature, has two typifiable names: $O$. indivisa Velen. (Nannfeldt 1966) and O. propinquata (P.Karst.) Harmaja (Harmaja 1976). Due to the rule of priority, the latter is the legitimate one (Harmaja 1976). (iii) The specimen already originally named $P$. bufonia would appear to represents true type material as it has been collected prior to the publishing of the protologue. (iv) P. felina, or O. felina (Pers.) Bres., may be a synonym of $O$. alutacea. (v) $P$. grandis would appear best to be treated as a nomen dubium et confusum: the name has been used in several senses in the literature and the only specimen with unsure original identification belonging to $O$. onotica. (vi) The name P. umbrina can be considered as referring to the same species as $P$. bufonia published later but sanctioned by Fries; fortunately, the epithet bufonia is used for the species in question more commonly than umbrina. Nannfeldt (e.g., 1966) used the epithet bufonia. 


\subsection{Rehabilitation of Peziza cantharella Fr.}

Peziza cantharella Fr., Syst. mycol. 2: 48. 1822. - Otidea cantharella (Fr.) Quél., Enchir. fung. 275. - Flavoscypha cantharella (Fr.) Harmaja, Karstenia 14: 107. 1974 [non Flavoscypha cantharella sensu Harmaja $1974=O$. concinna]. - Type material most probably lacking (Harmaja 1974a).

Peziza caligata Nyl., Not. Sällsk. F. Fl. Fennica Förh. 10: 8. 1868 (preprint: Obs. Pezizas Fenniae). - Otidea caligata (Nyl.) Sacc., Syll. fung. 8: 95. 1889. - Holotype: Finland, Uusimaa, Helsinki, 1850 W. Nylander $(\mathrm{H})(\mathrm{Nan}-$ nfeldt 1966; also studied by me).

The protologue of $P$. cantharella describes a fungus with split, shortly stipitate apothecia, the yellow colour of Cantharellus cibarius, and occurrence in spruce forest in southern Sweden. Only quite recently I came to the conclusion that the forgotten or misapplied (as Flavoscypha cantharella for O. concinna, e.g by Harmaja 1974) name Peziza cantharella Fr. clearly refers to the very poorly known species that Nannfeldt (1966) brought into publicity as $O$. caligata (Nyl.) Sacc. Breasadola (1933: pl. 1227) may be the only author after Fries that has recognized $O$. cantharel$l a$ in this - as I believe - original sense (though his image shows too pale apothecia).

As Nannfeldt (1966, as O. caligata) suggested, O. cantharella is obviously a "taiga species" with a European distribution essentially restricted to the northeastern part of the continent, with some occurrences on the mountains of Central Europe.

\section{Previously unreported responses of pigment encrustations to Melzer's reagent}

The crystalloid appearing, coloured encrusted pigment that in Otidea species covers the cells of the outermost of three excipular layers (or the outer of two layers), composed of $t$. prismatica, responds in Melzer mounts of dried apothecia in three different ways: $(i)$ the encrustations remain as such, (ii) the encrustations convert, in part or seemingly completely, into small red-tinged (cinnabar, brown-red, red-brown, fulvous), easily detached particles (in $O$. caeruleopruinosa, the latter appeared in the section of fresh apothecium as well), or (iii) the encrustations melt, in part or seemingly completely, into differently sized, amber (brownish golden or fulvous) drops that usually contain likewise differently sized, hyaline internal droplets. If the excipulum is composed of three layers (as in most species), also the intercellular matter in the middle $t$. angularis layer sometimes displays the respective responses. In Melzer mounts, also small brown (detached?) crystals, small hyaline drops, and brownish colour may be present in and by the ectal excipulum. Even the contents of excipular hyphae and the possible indistinct encrustations on the hyphae of the basal mycelia of the apothecia occasionally appear to give somewhat similar responses.

The melting into amber drops was observed in mounts with boiled cotton blue (only mountant tested) in a dried specimen of the North American $O$. unicisa (see below).

The Melzer responses should preferably be observed immediately after the mount has been prepared. An incomplete converting or melting of the encrustations may at least sometimes result from the (too thick?) apothecium section not getting into contact with the mountant.

The reddish particles are conspicuously present in e. g. O. bufonia and O. leporina sensu auct. The amber drops are met with in e.g. $O$ onotica, $O$. phlebophora (very abundantly), and $O$. tuomikoskii. The encrustations of $O$. concinna respond in all three ways.

These converting and melting responses, admittedly often indistinct, apparently have not been observed previously in Otidea, or at least not been reported. Their constancy and taxonomic significance requires further study. However, with several closely related species included, I was forced to use these Melzer responses in the below key.

\section{Descriptions of three new species from Finland}

\subsection{Otidea angusta Harmaja, n. sp. - Fig. 1}

Otideae nannfeldtii satis similis. Ab ea praecipue differt apotheciis maioribus, apicibus paraphysium 2.0-2.5(-3.5) $\mu \mathrm{m}$ crassis et cellulis terminalibus paraphysium 30-50 $\mu \mathrm{m}$ longis. Sporae 8.0-9.8 × 4.5-5.2 $\mu \mathrm{m}$. - Typus: Finland. Varsinais-Suomi. Lohja, Jalassaari, Ahtiala, E of Heimo house, mixed somewhat moist rich woods, in mixed litter, 6682:3329, 23.VIII.1965 H. Harmaja $(\mathrm{H})$. 
Apothecia (dry) 1.5-3 cm high and 0.3-1.3 $\mathrm{cm}$ wide, split, narrowly ear-shaped, with very short stipe-like base; rather hard in consistency. External surface medium or dark fulvous, mat, glabrous to the bare eye (subglabrous under a lens). Hymenium pale brown. Basal mycelium not pure white but very faintly brownish. Odour lacking when dry (most probably also when fresh). Taste mild when fresh.

Spores 8.0-9.8 × 4.5-5.2 $\mu \mathrm{m}$, most oblongellipsoid, a proportion being fairly narrowly ellipsoid and some subfusiform, slightly inequilateral; wall hyaline, perfectly smooth; contents hyaline, with two large, equally-sized oil drops (which become less distinct towards maturity) and, in a minority of mature spores, one lateral (mostly) or central gaseous 'de Bary bubble'. Paraphyses $1.5-2.0(-2.5) \mu \mathrm{m}$ thick below, rather entangled, most curved (often weakly so), the remainder being hooked; terminal cells 30 $50 \mu \mathrm{m}$ long; great majority simple and smooth above but a few bearing one swelling on concave side; apices, in great majority, not enlarged or very slightly so (in a very few distinctly), the enlarged tips being subcapitate and measuring 2.0-2.5(-3.5) $\mu \mathrm{m}$. Asci maturing at different times, pleurorhynchous, eight-spored; walls very thin, inamyloid. Excipulum three-layered. (i) Ental layer of $t$. intricata with hyphae $2-8 \mu \mathrm{m}$ in diam.; walls very thin, hyaline. (ii) Middle layer not sharply delimited towards the ental one, of somewhat untypical $t$. angularis, $60-90 \mu \mathrm{m}$ and 4-5(-6) cell rows thick; cells 7-30(-35) × 6-25 $\mu \mathrm{m}$. (iii) Outermost layer consists of more or less separate, fairly sharply delimited irregular to conical warts (often partly collapsed in mounts of dried apothecia) of $t$. prismatica, $40-80 \mu \mathrm{m}$ high and 40-60 $\mu \mathrm{m}$ wide basally: hyphal chains constricted at septa, with cells that are smaller than those in the middle layer, end cells 10-25 $\times$ 5-8 $\mu \mathrm{m}$, elongated, of variable shape; cell walls thin, hyaline, covered with $(a)$ hyaline small crystals and/or hyaline thin mucilage in places, and $(b)$ coloured encrusted pigment that melts into conspicuous amber drops of variable size, of partly irregular shape, possessing hyaline inclusions; these drops are soon abundant in the Melzer mount in and around t. prismatica (and the lower part of $t$. angularis). Basal mycelium of hyphae $2.5-5 \mu \mathrm{m}$ thick, interwoven, septate; walls thin, subhyaline.

Ecology. In mixed, somewhat moist rich woods ('lehtokorpi' in Finnish) with Picea abies, Betula pendula, Corylus avellana etc., on somewhat calcareous soils. Substrate abundant mixed litter comprising leaves of spruce and deciduous trees, plus remnants of herbs and ferns.

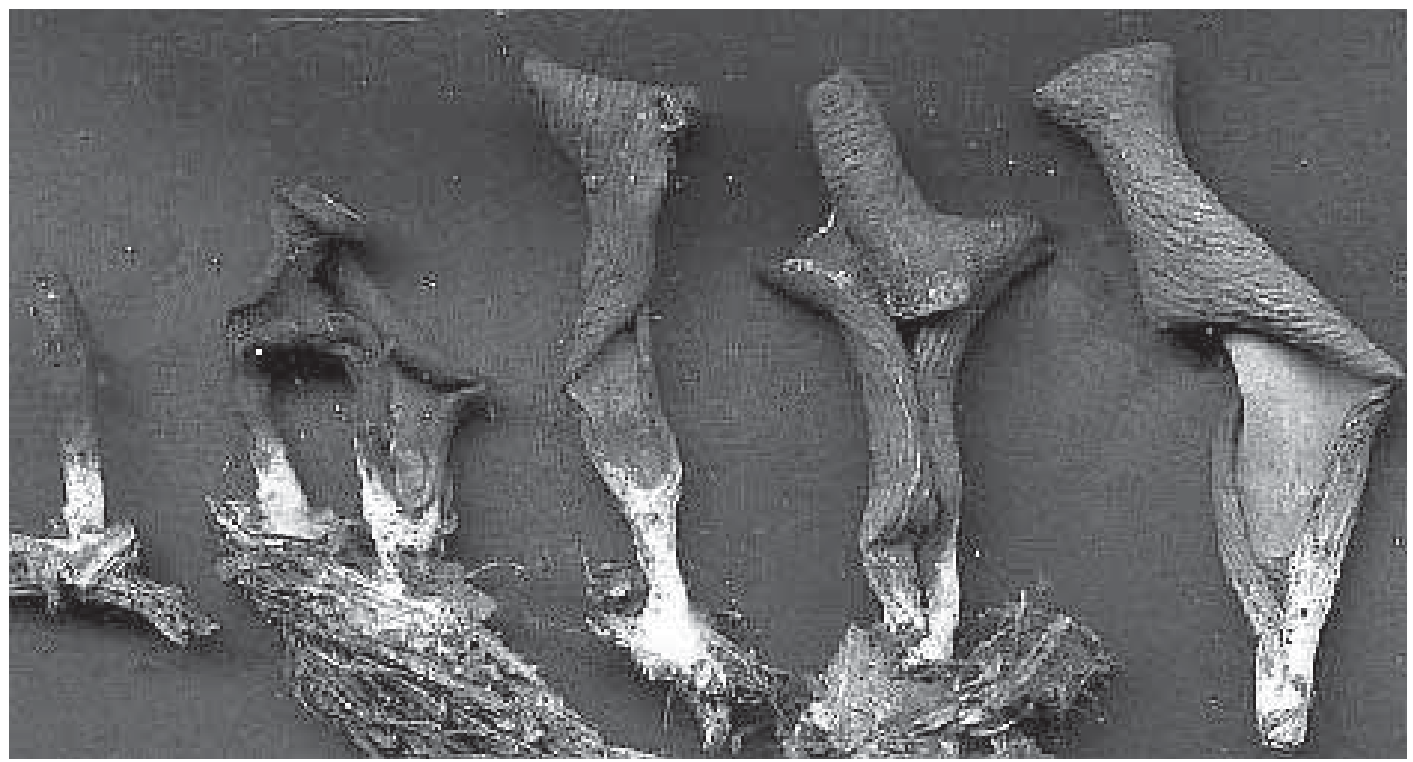

Fig. 1. Otidea angusta Harmaja, dried apothecia $\times 2.3$ (holotype). 
According to my scanty field notes, the apothecia were "more grey-tinged when fresh" (than in the dried condition).

Otidea angusta is closely related to $O$. nannfeldtii Harmaja (Harmaja 1976). Microscopically, it is differentiated from the latter by the thinner paraphysis tips $(2.5-5 \mu \mathrm{m}$ thick in $O$. nannfeldtii), and the shorter end cells of the paraphyses (50-100 $\mu \mathrm{m}$, i.e. exceptionally long, in $O$. nannfeldtii). Also, the spores of the new species may be slightly smaller (though only one specimen of each species is known so far). Macroscopically, the dried apothecia of $O$. angusta display the following differences to $O$. nannfeldtii: they are taller and with slightly thicker flesh, they have a short stipe-like base, their basal mycelium is very slightly coloured (faintly brownish); the apothecial outside (under the lens) is indistinctly pubescent (vs. practically glabrous), longitudinally low wrinkled, and somewhat darker, fulvous.

Otidea angusta also somewhat resembles $O$. tuomikoskii Harmaja (Harmaja 1976) but the fresh hymenium of the latter is yellowish while the yellow colour is absent from the apothecia of $O$. angusta. Moreover, the apothecial outside of $O$. angusta is more finely roughened, and the dry apothecia are inodorous; in O. tuomikoskii the external surface of is echinulate-papillate (usually even with bare eye) and the dry apothecia usually possess a faint indefinable odour. For a good illustrated description $O$. tuomikoskii, see Van Vooren et al. (2008, including the cover of the journal issue).

\subsection{Otidea caeruleopruinosa Harmaja, n. sp. - Fig. 2}

Apothecium scissum, extus caeruleopruinosum. Hymenium albidum. Sporae 10.0-12.0 × 5.0-5.5 um. - Typus: Finland. Varsinais-Suomi. Lohja, Jalassaari, Ahtiala, Alho, nature reserve "Ahtialan lehto". Rich, predominantly deciduous (Quercus robur, Corylus avellana etc.), woods on calcareous soils, on bare, clayey mull, u. c. Otidea alutacea, O. bufonia, O. flavidobrunneola, 6682:3328, 20.IX.1978 H. Harmaja (H). - Another specimen examined (notes of the colours of fresh apothecium were not made): Finland, Lohja, the same place, u. c. Otidea alutacea, $O$. flavidobrunneola, O. phlebophora, 30.VIII.1967 H. Harmaja (H).

Apothecium (fresh) $5.5 \times 3.0 \mathrm{~cm}$, split, elongate but appearing somewhat truncate as being bent backwards, with indistinct stipe-like base; moderately hygrophanous, fading from below in a fairly regular manner. Outside $(i)$ with pale dirty brown ground colour (13E6, 13F6) when moist; (ii) pale brown (11E5) or pale grayish brown (12C4) when faded (after extra water has

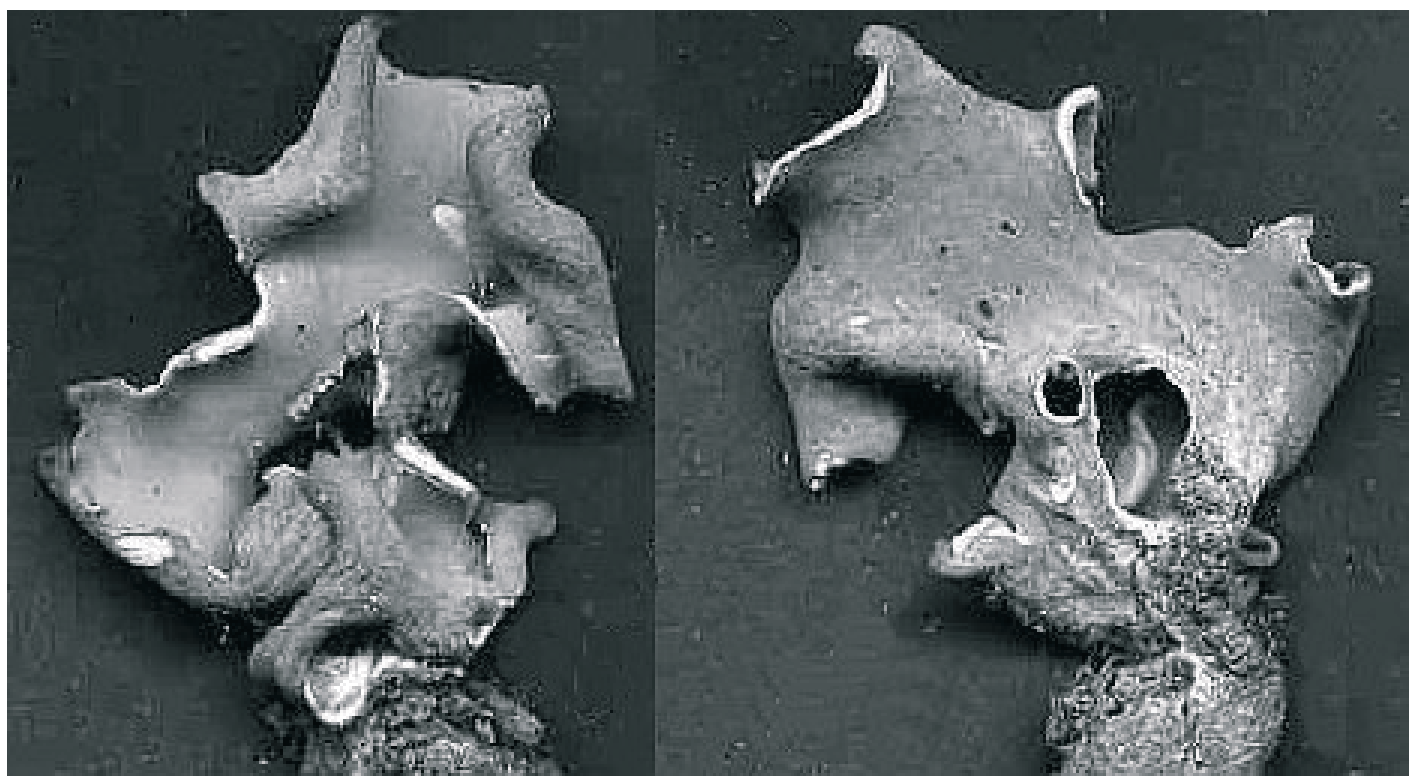

Fig. 2. Otidea caeruleopruinosa Harmaja, dried apothecium in ventral (left) and dorsal views $\times 3.5$ (holotype). 
evaporated); (iii) on that ground colour, surface pruinose with very small dark blue (partly lilac blue) warts that are barely visible to the naked eye (see below). Hymenium watery whitish when moist, pale buff (9E2) when faded. Basal mycelium scanty, pure white. Context hygrophanous, 1.1-1.3 mm thick, pure white when faded. Odour faintly of rubber. Taste mild.

Apothecia (dry) elongate at first, becoming broadly elongate or subtruncate (even truncate?) in age; outside tan, mat, appearing glabrous but finely pubescent under the lens; hymenium more or less pale brown (slightly paler than outside); basal mycelium pure white; odour very faint, indefinable.

Spores $10.0-12.0 \times 5.0-5.5 \mu \mathrm{m}$, great majority narrowly ellipsoid with some oblong-ellipsoid and subfusiform ones, slightly inequilateral; wall hyaline, perfectly smooth; contents hyaline, with two large, equally-sized oil drops (which become less distinct towards maturity) and - in a considerable minority of mature spores - one central or lateral gaseous 'de Bary bubble'. Paraphyses 2.0-4.0(-7.5) $\mu \mathrm{m}$ thick below, slightly entangled, most curved and some hooked, a few (often the thin ones) being straight; terminal cells $25-50 \mu \mathrm{m}$ long; great majority simple and smooth above, the remainder bearing 1-2 mostly low swellings on concave side; apices gradually slightly to moderately enlarged to reach a width of 2.5-5.0 $\mu \mathrm{m}$ (extreme apex slightly tapering). Asci maturing at different times, pleurorhynchous, eight-spored; walls very thin, inamyloid. Excipulum two-layered. (i) Ental layer of $t$. intricata with mostly narrow hyphae $2-7 \mu \mathrm{m}$ in diametre, the latter being mixed with a few ones inflated up to $17 \mu \mathrm{m}$ in the upper part; walls very thin, hyaline. (ii) Ectal layer not sharply delimited towards the ental one, of $t$. prismatica with tendency towards $t$. angularis (especially in its inner part), roughly differentiated to an inner and an outer part; (ii.i) inner part voluminous, $100-130 \mu \mathrm{m}$ and $4-5$ cell rows thick: cells of variable size, $10-50(-62) \times 5-22 \mu \mathrm{m}$, commonly long and rather narrow, their contents most probably converting into small fulvous or brown-red particles (on contact with Melzer's); (ii.ii) outer part of more or less separate irregular to conical tufts $40-100 \mu \mathrm{m}$ high and $40-80 \mu \mathrm{m}$ thick basally: hyphal chains constricted at septa, cells (partly collapsed in mounts from dried apoth- ecia) smaller than those of inner part, end cells 10-27 × 5-12 $\mu \mathrm{m}$, most clavate; cell walls thin, hyaline, covered with distinct hyaline mucilage and on it abundant brown-red, easily detached small particles, contents seemingly as in inner part. Basal mycelium of hyphae 2-5 $\mu \mathrm{m}$ thick, interwoven, septate; walls thin, hyaline, covered with very scattered small, brown-red granules.

Ecology. In rich, predominantly deciduous woods on calcareous soils. Quercus robur and Corylus avellana are important spontaneous components in the tree layer. In addition, Alnus incana, Betula pendula, Picea abies, Populus tremula, Prunus padus, Salix caprea, and Sorbus aucuparia occur. Solitary or in dense rows on bare, clayey mull soil. - For more details about the site, see below in the section "Discussion" under $O$. flavidobrunneola.

The ground colour of the fresh apothecial outside is greyish pale brown, but very small blue warts give an effect of bluish pruina. This character is only observable in quite fresh and moist apothecia, the blue colour soon fading away, or disintegrating when the tissue begins to dry after collecting. The tiny warts appear lilac in places. The warts become larger towards the apothecial margin where they are easiest observed, the very margin being greyish blue to grayish violaceous. This infrequent colour must be that of the contents and/or the encrusted crystals of the $t$. prismatica tufts (= the warts) of the outer excipulum.

Two additional diagnostic characters of $O$. caeruleopruinosa are the spore length that represents a rare size class in Otidea, and the structure of the excipulum that lacks distinct $t$. angularis structure.

\subsection{Otidea flavidobrunneola Harmaja, n. sp. - Fig. 3}

Ab Otidea bufonia differt inter alia superficie exteriori apothecii pallidiore, hymenio flavido et sporis minoribus, 9.5-10.2 × 4.8-5.2 $\mu \mathrm{m}$. - Typus: Finland. Varsinais-Suomi. Lohja, Jalassaari, Ahtiala, Alho, nature reserve "Ahtialan lehto". Rich, predominantly deciduous (Quercus robur, Corylus avellana etc.), woods on calcareous soils, on bare, clayey mull, u. c. Otidea alutacea, O. bufonia, O. caeruleopruinosa, 6682:3328, 20.IX.1978 H. Harmaja (H). 


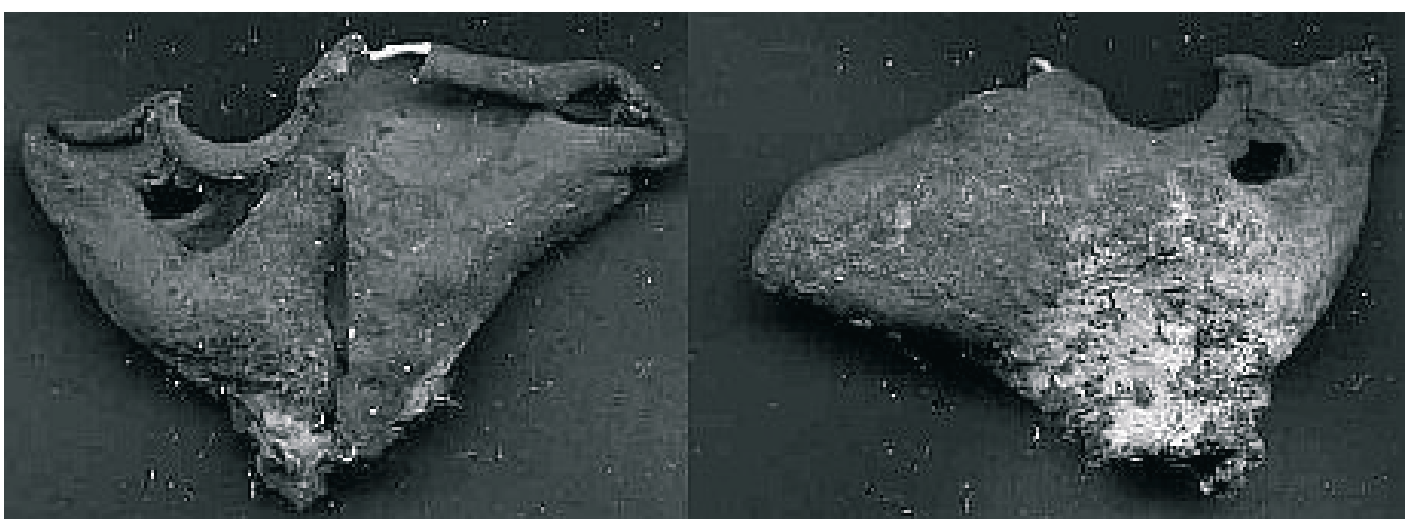

Fig. 3. Otidea flavidobrunneola Harmaja, dried apothecium in ventral (left) and dorsal views $\times 2$ (a specimen from type site, 30.VIII.1967 H. Harmaja).

Apothecia (fresh) 2.5-7.0 × 1.0-5.0 cm, subtruncate (almost truncate, with upper margin not strictly horizontal but slightly oblique sloping towards cleft), fairly narrow at first but usually wider in age to become almost as broad as high, stipe-like base absent or indistinct; moderately hygrophanous, fading from below in a fairly regular manner. Outside, when moist, pale yellowish-brown (slightly darker than 12H7), in places slightly darker brown with reddish tinge (13I8), near base fairly pale grey-brown; practically retaining its colour $(12 \mathrm{H} 7)$ when faded (after extra water has evaporated); surface indistinctly pruinose with tiny, at first pale brown then (upwards) copper brown warts on pale ochraceous yellow ground. Hymenium pale yellowish (11E2, 11E3) when moist, pale yellowish buff (10H3) when faded. Basal mycelium very pale yellow. Context hygrophanous, $1.5-2 \mathrm{~mm}$ thick towards base, pure white when faded, Dipteran larvae common (in the type). Odour faintly (distinctly in drying) of rubber. Taste mild.

Apothecia (dry): outside medium brown (at times, locally pale brown upwards), mat, smooth to the bare eye but very finely roughened under the lens; hymenium more or less pale brown; basal mycelium pale orange; odour faint, indefinable.

Spores 9.5-10.2 × 4.8-5.2 $\mu \mathrm{m}$, most oblongellipsoid with some narrowly ellipsoid and some oblong ones, slightly inequilateral; wall hyaline, perfectly smooth; contents with two large, equally-sized oil drops (which become less conspicuous towards maturity) and - in a variable pro- portion of released spores - one lateral or central gaseous 'de Bary bubble'. Paraphyses 2.2-3.5 $\mu \mathrm{m}$ thick below, most curved, some hooked, and some (often the thinnest ones) straight; terminal cells $25-45 \mu \mathrm{m}$ long; great majority simple and smooth above, a few possessing one low swelling on concave side; apices gradually slightly enlarged to reach a width of 2.2-4.2 $\mu \mathrm{m}$ (extreme apex, however, usually tapering). Asci maturing at different times, pleurorhynchous, eightspored; walls very thin, inamyloid. Excipulum two-layered. (i) Ental layer of $t$. intricata with hyphae 3-8(-12) $\mu \mathrm{m}$ thick; walls thin, hyaline; in places with very scanty pale melleous contents that most probably convert into small fulvous particles (on contact with Melzer's); (ii) Ectal layer gradually changing from ental one, of $t$. prismatica with tendency towards $t$. angularis in places in its inner part, roughly differentiated to an inner and an outer part; (ii.i) inner part 60-80 $\mu \mathrm{m}$ and $4-6$ cell rows thick: cells of variable size, 5-30 × 4-22 $\mu \mathrm{m}$, with pale melleous contents that most probably converts into small fulvous particles on contact with Melzer's; (ii.ii) outer part of rather indistinct, confluent or almost separate irregular tufts 30-90 $\mu \mathrm{m}$ high and 30-60 $\mu \mathrm{m}$ thick basally: hyphal chains constricted at septa, cells roughly of same size as those of inner part, end cells $10-25 \times 5-10 \mu \mathrm{m}$, all clavate; cell walls thin, hyaline, covered with distinct hyaline mucilage and on it abundant red-brown, partly easily detached small particles, contents seemingly as in inner part. Basal mycelium of hyphae 3.5-5 (-7) $\mu \mathrm{m}$ thick, interwoven, septate; walls 
thin, subhyaline, covered with small reddish, easily detached granules.

Ecology. (Lohja site) In rich, predominantly deciduous woods on calcareous soils. Quercus robur and Corylus avellana are important spontaneous components in the tree layer. In addition, Alnus incana, Betula pendula, Picea abies, Populus tremula, Prunus padus, Salix caprea, and Sorbus aucuparia occur. Apothecia solitary or in row on bare, clayey mull soil. (For more details about the site, see section Discussion below.) (Nurmijärvi site) In park with rich soils, under non-spontaneous Quercus robur. Some apothecia on bare, clayey mull soil.

Specimens examined: FINLAND. Varsinais-Suomi: Lohja, Jalassaari, same place as holotype (see above), u. c. Otidea alutacea, O. caeruleopruinosa, O. phlebophora, 30.VIII.1967 H. Harmaja (H); Lohja, holotype (H). - Uusimaa: Nurmijärvi, Kirkonkylä, Pappilan puisto, 6707:3379, 8.IX.1986 P. Askola 2015 (H); Nurmijärvi, same site, 16.IX.1987 P. Askola $2220(\mathrm{H})$.

O. Alavidobrunneola somewhat reminds of $O$. bufonia in habit and habitat. However, the former has paler, yellowish fresh hymenium and shorter and differently shaped spores.

The following features are also peculiar to $O$. flavidobrunneola: (i) the apothecial outside, hymenium and basal mycelium get darker in drying, (ii) the asci and spores apparently mature tardily, (iii) the spores are unusually uniform in size.

The originally very pale yellow basal mycelium of the apothecia characteristically dries to pale orange, a colour unique in the genus in this structure. The colour of the basal mycelium was already found diagnostic at the species level in Otidea by Harmaja (1976). For instance, the basal mycelium is pure white both in the fresh and dry condition in O. leporina sensu auct. and $O$. propinquata while that of $O$. bufonia is pale brown and that of $O$. tuomikoskii very pale rusty brown.

The faint, slightly unpleasant rubber-like smell emitted by the fresh apothecia of the present species is also observable in a few other species of Otidea, e. g. O. bufonia and O. onotica. The odours should be noted separately in fresh and dry apothecia. The faint odour present in the dry apothecia of some species such as $O$. flavidobrunneola, O. onotica and O. tuomikoskii is indefinable but some people may sense it pleasant. Most species are inodorous both when fresh and when dry.

The site where the type and another collection of $O$. flavidobrunneola (and that of $O$. caeruleopruinosa, see above) were found, also houses a few planted or sown trees of the exotic Larix sibirica (though they now have been removed for the most part if not totally). Exacting vascular plants are few, including Epipactis helleborine, Mercurialis perennis and the apomictic Ranunculus platycolpoides. Abundant occurrence of the southern and exacting moss Eurhynchium angustirete also deserves to be mentioned.

Already in late 1960's I noticed how exceptionally rich this rather small grove is in macrofungus species though the vascular plants of the place do not include rarities. This grass-herb forest houses the most interesting assembly of Otidea species presently known in Finland. The grove is nowadays protected by law as nature reserve.

During years, I have found unusually many interesting fungus species in this area, many of them having fruited at the same time as Otidea flavidobrunneola. Some species are immediate associates of $O$. flavidobrunneola and $O$. caeruleopruinosa, others growing slightly farther in the spruce-dominated portion. Many calcicolous or calciphilous species are found, some species being mycorrhizal associates of Quercus robur or Corylus avellana, and many species having a more or less southern distribution in Finland.

All in all, the interesting species of macrofungi collected from this this nature reserve (specimens of most of them are or will be deposited in H) are as follows: Ascobolus aff. viridis, Boletopsis leucomelaena, Cystolepiota seminuda, Hebeloma sinapizans, Helvella elastica, H. sulcata, Lactarius pyrogalus sensu auct., Lactarius vellereus coll., Leccinum duriusculum, Mycena polygramma, Otidea alutacea, O. bufonia, O. caeruleopruinosa, O. flavidobrunneola, $O$. phlebophora, O. lohjaënsis nom. prov. (the last-named possibly only immediately beyond the border of the nature reserve), Sebacina epigaea, Pithya vulgaris, Scutellinia trechispora, Skeletocutis nivea, Tricholoma columbetta, T. sulphureum. 


\section{A synopsis of the Finnish species of Otidea}

In the habitat descriptions, Corylus $=$ C. avellana, Picea $=$ P. abies, Pinus $=$ P. sylvestris, and Quercus $=Q$. robur.

\subsection{A key, based on macroscopic and ecological characters}

Otidea angusta and $O$. nannfeldtii have been excluded as the characters of their fresh apothecia are inadequately known.

1 Fresh apothecial outside, more distinctly upwards, with blue, partly lilac, pruinosity on pale brown ground; fresh hymenium watery whitish (basal mycelium pure white both when fresh and when dry; rich woods with Quercus and Corylus;" on bare clayey mull soil) O. caeruleopruinosa

1' Fresh apothecial outside yellow or brown, never with blue or lilac tones; fresh hymenium truly coloured, of some tinge of yellow or brown 2

2 Either outside or hymenium, or both, display some tinge of true yellow in a fresh apothecium ... 3

2 ' Both outside and hymenium of some tinge of brown when fresh (rarely a faded, i.e. half-dried hymenium may temporarily assume a tinge with quite yellowish component) 10

3 Fresh apothecial outside lemon (sulphur) yellow (citrine); (fresh hymenium pale pinkish buff or at least with a rose hue; outside fairly pale brown when dry; rich woods on calcareous ground, usually with Corylus, also Quercus and Tilia cordata may be present; on bare mull soil) (compare also O. phlebophora)

3' Fresh apothecium possessing other tinges of yellow 5

4 Apothecia several $\mathrm{cm}$ high, more or less elongated, ear-shaped, basally smooth or somewhat rugose. O. concinna

4' Apothecia a few $\mathrm{cm}$ in diam. at most, truncate (i.e., not elongated opposite to the cleft; a few entire ones may be present in a stand), irregular in shape and often laterally compressed, basally more or less ribbed. O. subconcinna nom. prov.

5 Apothecia entire and cupulate, though usually irregular in shape and laterally compressed with age, with basal ribs that may be branched and anastomosed and have pits between (cups $2 \mathrm{~cm}$ in diametre at most; outside and hymenium ochraceous yellow when fresh; outside medium brown when dry; flesh very thin; rich woods in calcareous ground with Corylus, Quercus or Tilia cordata may also be present; on bare clayey mull soil) O. phlebophora

5, Apothecia split, basally smooth or somewhat rugose 6

$6 \quad$ Fresh outside brown, hymenium yellowish ….................................................................... 7

6' Both outside and hymenium with yellow tinges when fresh............................................... 8

7 Apothecia mostly narrow and clearly longer than wide, ear-shaped; outside finely echinulatepapillate usually even by bare eye; basal mycelium slightly brownish both when fresh and when dry; mesic heath forest and grass-herb forest, at times in ant hills (Formica); in litter that usually comprises spruce needles (compare also $O$. papillata).

O. tuomikoskii

7' Apothecia subtruncate, almost as broad as high with age; outside almost smooth, finely pruinose; basal mycelium almost white when fresh but pale orange when dry; either grass-herb forest under Quercus and Corylus or park with Quercus; on bare clayey mull soil.

O. flavidobrunneola

8 Apothecia a few cm in size, truncate; occurrence in Formica ant hills (in old mesic heath forest; substrate a mixture of Picea needles and bare soil) O. formicarum

8' Apothecia up to c. $8 \mathrm{~cm}$ high, mostly elongate and ear-shaped, at times pseudotruncate (bent backwards) or almost truncate; not occurring in ant hills 
9 Apothecia mostly not stipitate; outside with brownish roughness, especially when dry; hymenium usually with rose tinge in places; basal mycelium pale yellow when fresh, slightly brownish when dry; grass-herb woods, often deciduous, in nutrient-rich, often calcareous ground; on more or less bare mull soil

O. onotica

9' Apothecia not rarely with short stipe; outside indistinctly pruinose; hymenium without pinkish areas; basal mycelium practically pure white; mostly mesic heath forest (MT), also in dry heathforest or in rich woods, usually with Picea; in litter (esp. spruce needles),

often among mosses

O. cantharella

10 Apothecia cupulate, unsplit, stipitate at times (medium to dark brown; basal mycelium pure white; rich or mesic forest, calciphilous; in litter [mostly spruce needles], often among moss)

10' Apothecia more or less ear-like, split, hardly stipitate O. propinquata

11 Apothecia more or less truncate, i.e. a split cup not elongated on the side opposite to the split (rarely somewhat elongated) (grass-herb woods in nutrient-rich, often calcareous ground; on more or less bare mull soil)

11' Apothecia more or less elongated, ear-shaped, may become "pseudotruncate" (bent backwards); rarely soon expanding to become almost rounded

12 Outside dark brown, hymenium concolorous or slightly paler; basal mycelium brownish

O. bufonia

12' Outside pale brown, hymenium - especially when dry - more or less darker, yellowish or medium brown; basal mycelium pure white O. alutacea

13 Apothecia pale brown; outside beset with fine, somewhat darker papillae well visible to bare eye (grass-herb woods on nutrient-rich, even calcareous ground; in litter) O. papillata

13' Apothecia medium or dark brown, often with a faint yellowish or ferruginous tint; outside glabrous, finely pruinose or finely tomentose

14 Grass-herb woods on calcareous ground or limestone rock outcrop; on more or less bare mull soil (apothecia mostly small: one measuring $1 \times 0.5 \mathrm{~cm}$ may be mature)..... O. lohjaënsis nom. prov. and $O$. savonica nom. prov.

14' More or less calcifugous species of heath forest and poorer site types of grass-herb forest; in leaf litter that usually comprises spruce needles .....

15 Apothecia spreading out to become almost rounded, like a mouse's ear, when full-grown (roughly reaching measures $4 \times 4 \mathrm{~cm}$, medium brown; basal mycelium pure white) .......... O. myosotis

15 ' Apothecia mostly rather narrow, like a hare's ear (shape broader at times) 16

16 Apothecia medium-sized, up to c. $5 \mathrm{~cm}$ high, medium brown when fresh, with medium thick context; basal mycelium pure white both when fresh and when dry ........ O. leporina sensu auct.

16' Apothecia small, $3.5 \mathrm{~cm}$ high at most, dark brown when fresh; basal mycelium whitish with pale rusty brown spots when fresh, slightly brownish when dry O. brunneoparva nom. prov.

\subsection{A key, based on microscopic characters}

All the microscopic characters, including the often subtle spore measures, are those observed in Melzer's. Only truly mature, i.e. hyaline and preferably discharged, spores should be studied (submature ones may be wider and slightly differently shaped). The "reddish particles" and "amber drops" are explained above in the section "Previously unreported responses of pigment encrustations to Melzer's reagent".

1 Spores $17-20 \times 9-10(-11) \mu \mathrm{m}$ 2

1' Spores shorter than $17 \mu \mathrm{m}$ and narrower than $9 \mu \mathrm{m}$ 3 
2 The curved or hooked apices of paraphyses partly with with swellings, partly ramose with true branches (check in truly mature apothecia) O. propinquata

2' The curved or hooked apices of paraphyses simple, without swellings (one low swelling, at most, may be present on the underside)

O. cantharella

3 At least half of the spores subfusiform to fusiform in shape (spore length within 11-16 $\mu \mathrm{m}$ and width within 5.0-7.5 $\mu \mathrm{m}$; encrustation on cells of ectal excipulum converting into small reddish, easily detached particles in Melzer's)

O. bufonia

3' All or almost all spores ellipsoid, oblong or ellipsoid-oblong (some subfusiform ones may be present)

4 All or most paraphyses with one to several swellings, at times even short true branches, on the undersides of their curved or hooked apices (check in truly mature apothecia) ....................... 5

4' All or at least half of the paraphyses without apical swellings; 1-3 low and indistinct swellings may be present on their curved or hooked undersides in not more than half of them .............. 8

5 At least part of paraphysis tips with true branches; spores $11-13.5 \times 6.5-7.5 \mu \mathrm{m} \ldots \ldots \ldots \ldots \ldots \ldots . .6$

5. Paraphysis tips with 1-4 swellings only (true branches very rare); spores 8.5-11 $\times 5-6 \mu \mathrm{m}$ (encrustations of ectal excipulum partly melting into amber drops in Melzer's) ....... O. tuomikoskii

6 Encrustations of ectal excipulum converting, partly or completely, into reddish particles in Melzer's O. leporina sensu auct.

6' Excipular encrustions responding differently in Melzer's 7

7 Excipular encrustations partly melting into amber drops in Melzer's O. brunneoparva nom. prov.

7' Excipular encrustations not getting transformed in Melzer's O. myosotis

8 Spores longer than $12 \mu \mathrm{m}$ 9

8, Spores shorter than $12 \mu \mathrm{m}$ 10

9 Spores 5.5-6.5 $\mu \mathrm{m}$ wide (12.0-14.0 $\mu \mathrm{m}$ long); roughly half of paraphysis tips with 1-3 low swellings on the underside; encrustations on at least the inner inflated excipulum cells melting into amber drops in Melzer's

O. onotica

9' Spores $6.2-7.3 \mu \mathrm{m}$ wide $(12.5-14.5 \mu \mathrm{m}$ long); a minority of paraphysis tips with 1-2 low swellings; excipular encrustations not getting transformed in Melzer's O. alutacea

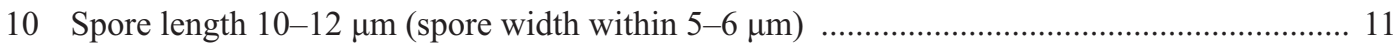

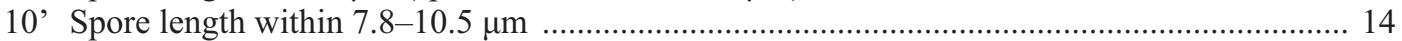

11 Most paraphyses straight in mature apothecia (paraphysis tips 3-5 $\mu \mathrm{m}$ thick; amber drops very abundant by ectal excipulum in Melzer mounts) ............................................. O. phlebophora

11' Usually most paraphyses curved apically in mature apothecia, a half of them may be straight at most (amber drops occurring in moderate amounts or lacking in Melzer's) 12

12 Amber drops present by ectal excipulum in Melzer's (brownish or reddish particles may also occur)

12' Amber drops absent (encrustations convert into reddish particles only) .... O. caeruleopruinosa

13 Spores 5-6 $\mu \mathrm{m}$ wide; most paraphyses curved apically; excipular encrustations partly melting into amber drops, partly converting into reddish particles in Melzer's (paraphysis tips 2.5-4.2 $(-5) \mu \mathrm{m}$ wide)

O. concinna

13' Spores c. $5 \mu \mathrm{m}$ wide; roughly half of paraphyses straight; amber drops and abundant brownish particles present by ectal excipulum (paraphysis tips $2-5.5 \mu \mathrm{m}$ wide) .. O. subconcinna nom. prov.

14 Excipular encrustations either converting into reddish particles or melting into amber drops in Melzer's

14' Excipular encrustations not responding to Melzer's in either way 18 
15 Encrustations converting into reddish particles in Melzer's (spore length 9.5-10.2 $\mu \mathrm{m}$ ) 16

15 ' Encrustations melting into amber drops in Melzer's

16 Spore width $5.5-6.5 \mu \mathrm{m}$ O. papillata

16' Spore width $4.8-5.2 \mu \mathrm{m}$ O. flavidobrunneola

17 Spores $8.5-10.5 \times 5.2-6.5 \mu \mathrm{m}$; paraphysis end cells 50-100 $\mu \mathrm{m}$ long; paraphysis apices $2.5-5.0$ $\mu \mathrm{m}$ wide.

O. nannfeldtii

17' Spores 8.0-9.8 × 4.5-5.2 $\mu \mathrm{m}$; paraphysis end cells 30-50 $\mu \mathrm{m}$ long; paraphysis apices 2.0-2.5 $(-3.0) \mu \mathrm{m}$ wide

O. angusta

18 Spores 5.5-6.5 $\mu \mathrm{m}$ wide (their length $8.5-10.5 \mu \mathrm{m}$ )

O. formicarum

18 ' Spore width within 4.5-5.5 $\mu \mathrm{m}$

19 Spores 8.2-10.0 × 4.5-5.2 $\mu \mathrm{m}$; paraphysis apices $2.5-4.5 \mu \mathrm{m}$ wide O. lohjaënsis nom. prov.

19 ' Spores $7.8-10.0 \times 5.0-5.5 \mu \mathrm{m}$; paraphysis apices $2-3 \mu \mathrm{m}$ wide O. savonica nom. prov.

\subsection{An annotated list of currently known Otidea species of Finland}

\section{O. alutacea (Pers.) Massee}

Grass-herb forests, also occurring in park-like habitats. Prefers the company of deciduous trees. Calciphilous. On more or less bare mull soil. Tolerates some human influence. Hemiboreal to northern boreal; also in "subalpine" conditions, i.e. in mountain birch (Betula pubescens ssp. czerepanovii) zone. Whole Finland but mostly in the south. Infrequent except in places in the south.

\section{O. angusta Harmaja}

Slightly moist, mixed grass-herb forest ('lehtokorpi' in Finnish). Probably calciphilous. In mixed litter (see above in the description). Hemiboreal. One find from SW Finland (V: Lohja). - O. angusta, together with O. lohjaënsis nom. prov., has the narrowest spores in the genus.

\section{O. brunneoparva nom. prov.}

Mesic heath forest, especially on ant hills. Probably prefers old-growth forest. Substrate decaying spruce needles. Southern boreal. Infrequent in southern Finland (Lammi; most probably also other localities).

\section{O. bufonia (Pers. : Fr.) Boud.}

[O. umbrina (Pers.) Bres. sensu auct.; see also above section "Identification of Otidea specimens of Herbarium Persoon (L)"]

Grass-herb woods; sometimes in park-like habitats, rarely eutrophic (spruce-)hardwood swamps (especially in the north?). Not likely to be associated with a certain tree species. Tolerates some human influence. Calciphilous-calcicolous. On more or less bare mull soil (very rarely essentially among moss and litter). Hemiboreal to northern boreal; also in "subalpine" conditions, i.e. in mountain birch (Betula pubescens ssp. czerepanovii) zone. Whole Finland. Uncommon, especially northwards.

Some variability is displayed in the shape of the apothecium, the darkness of the hymenium, and the size and shape of the spores. A few specimens possess short spores, $11-13.0 \mu \mathrm{m}$; this length reminds of the North American O. smithii Kanouse (Kanouse 1950), which, however, is different in other respects. - A curious type of striate pigment encrustation on excipular hyphae was observed in some Finnish specimens but this remained unpublished. The first to publish on this character were Korf and Zhuang (1991). They consider the presence of this feature, unique in Otidea and Pezizales, to be diagnostic of $P$. bufonia.

The name $O$. grandis (Pers.) Rehm, too, has at times been used for the present species (see also above the section "Identification of Otidea specimens of Herbarium Persoon (L)").

\section{O. caeruleopruinosa Harmaja}

Deciduous grass-herb forest with spontaneous Quercus and Corylus. Apparently calcicole. On bare clayey mull soil. Hemiboreal. Very infrequent, in SW Finland (V: Lohja, one place).

6. O. cantharella (Fr.) Quél. 
O. caligata (Nyl.) Sacc. (see above section "Rehabilitation of Peziza cantharella Fr.")

[O. abietina (Pers. : Fr.) Fuckel sensu Breitenbach and Kränzlin (1984)]

Especially mesic heath forest (MT site type) but also in dry heath forest and grass-herb forest. Prefers the company of Picea. May somewhat prefer old-growth forest. Calcifuge. Mostly in needle litter, at times among mosses. Hemiboreal to northern boreal. Uncommon to scattered. Whole Finland but infrequent or lacking in extreme south and extreme north. - An almost totally forgotten species which is still very poorly known, partly due to its essentially north-eastern distribution in Europe (see section "Rehabilitation of Peziza cantharella Fr." above).

\section{O. concinna (Pers. : Fr.) Sacc.}

[Flavoscypha cantharella (Fr.) Harmaja sensu Harmaja (1974), Dennis (1978: Pl. VIII E, not "D" as given)]

Deciduous grass-herb forest with spontaneous Quercus and Corylus. Calcicole. On bare clayey mull soil. Hemiboreal. One locality in SW Finland (V: Turku).

\section{O. flavidobrunneola Harmaja}

One locality comprises grass-herb forest with spontaneous Quercus and Corylus, another one is park with non-spontaneous Quercus. Apparently prefers the company of deciduous trees. Most probably calcicole. On bare clayey mull soil. Tolerates some human influence. Hemiboreal and southern boreal. Very infrequent, in southernmost Finland (V: Lohja and U: Nurmijärvi).

\section{O. formicarum Harmaja}

Mesic heath forests, in ant hills (of Formica spp.). Probably prefers old-growth forest. Calcifuge. Substrate a mixture of, often scanty, spruce needles and bare soil; often among low mosses. Southern to northern boreal. Infrequent from southern to northern Finland.

The pale orange response to ultraviolet light (wavelength $254 \mathrm{~nm}$; Harmaja 1976) is unique in the genus. - Salo et al. (2006) published a colour photo of the species in situ.

10. O. leporina (Batsch : Fr.) Fuckel sensu auct. Mainly mesic, rarely dry, heath forests; at times in the poorer site types of grass-herb forest. Pre- fers the company of Picea. Calcifuge. Mostly in needle litter of spruce, at times among mosses. Hemiboreal to northern boreal. Almost whole Finland (probably lacking in northern Lapland). Common or fairly common.

The colours and degree of hygrophanity of the apothecia vary somewhat. - According to Franchi et al. (1999) Peziza leporina Batsch : Fr. should be typified with a fungus that is currently known as Helvella silvicola (Beck ex Sacc.) Harmaja. The former name would be the oldest one for this fungus, and consequently these authors made the new combination Helvella leporina (Batsch : Fr.) Franchi, L.Lami \& M.Marchetti. If this is accepted, a valid specific epithet for the present Otidea species should be searched for (if in existence).

\section{O. lohjaënsis nom. prov.}

Grass-herb woods. May prefer the company of Picea. Calciphilous. Substrate bare mull soil. Hemiboreal. Very infrequent, SW Finland (V: Lohja, some localities). - The present species, together with $O$. angusta, has the narrowest spores in the genus.

\section{O. myosotis Harmaja}

Mesic heath woods and poorer site types of grass-herb forest. May prefer the company of Picea. In needle litter of spruce, at times among mosses. Hemiboreal and southern boreal (most probably also northwards). Infrequent, in southern Finland.

\section{O. nannfeldtii Harmaja}

Spruce forest (apparently of a fairly rich site type). Probably calciphilous. In litter. Hemiboreal. One locality in SW Finland (A: Lemland).

\section{O. onotica (Pers. : Fr.) Fuckel}

Grass-herb forest, also occurring in park-like habitats. Prefers the company of deciduous trees. Calciphilous. On more or less bare mull soil. Tolerates some human influence. Hemiboreal and southern boreal. Mostly uncommon but not infrequent in places in SW Finland.

\section{O. papillata Harmaja}

Grass-herb forest. Most probably calciphilous. Substrate litter that is mainly composed of spruce needles. Middle boreal. Very infrequent. - The spores are uninucleate in the holotype (observed 
useing acetocarmine staining, with the $\mathrm{KOH}$ pretreatment described in Harmaja 1974b). - For a good illustrated description O. papillata, see Van Vooren et al. (2008).

\section{O. phlebophora (Berk. \& Broome) Sacc.}

Flavoscypha phlebophora (Berk. \& Broome) Harmaja (Harmaja 1974)

Deciduous grass-herb woods with Corylus. Spontaneous Quercus also present in one locality. Calcicole. On bare clayey mull soil. Hemiboreal. Very infrequent in SW Finland (V: Lohja, two localities).

Differs from O. integra (Bres.) Harmaja (Harmaja 1986) through: slightly smaller apothecia which are ochraceous yellow throughout when fresh (vs. with citrine outside and pale pinkish buff hymenium), predominantly straight (vs. predominantly curved) paraphyses, and thinner paraphysis tips (3-5 $\mu \mathrm{m}$ vs. up to $7.5 \mu \mathrm{m}$ thick).

The colouration of fresh apothecia of $O$. phlebophora as given in the present paper corresponds to the protologue and to my field observations on the first Finnish find of the species. The colours were given erroneously or inaccurately by me previously (Harmaja 1974 and 1986).

\section{O. propinquata (P.Karst.) Harmaja}

O. indivisa Velen. (Nannfeldt 1966, Harmaja 1976; lectotype studied)

[O. abietina (Pers. : Fr.) Fuckel sensu auct.; see above section "Identification of Otidea specimens of Herbarium Persoon (L)"]

Mostly grass-herb forest, also in mesic heath forest. Possibly always with Picea. Calciphilous. Always in litter; mostly in spruce needles (also e.g. in leaves of Betula alba coll., leaves of Alnus incana, Pinus and ferns, in decaying herbs, and on decaying wood); often among mosses (decaying their basal parts?). Hemiboreal to northern boreal. Almost whole Finland (lacking in northern Lapland). Uncommon.

The apothecium may be differentiated into a cup and a true stipe (up to $3 \times 0.8 \mathrm{~cm}$ in deep moss) though the latter, unlike with the species of Sowerbyella Nannf., does not penetrate into the substrate proper. The deepness of the apothecial brown colour varies, likewise the shape of the spores: the latter may be predominantly el- lipsoid or subfusiform in a considerable proportion. - O. propinquata would appear to avoid the western and oceanic parts of Europe.

\section{O. savonica nom. prov.}

Limestone rock outcrop in fairly rich woods dominated by Picea. Maybe calcicole. On more or less bare mull soil. Southern boreal. Hitherto, only known from one locality in east-central Finland (PS: Kuopio).

\section{O. subconcinna nom. prov. - Fig. 4}

?Otidea cantharella var. minor Boud., Icones mycol. 4: 181. 1905-1910. - Flavoscypha cantharella var. minor (Boud.) Häffner, Rheinland-Pfälzisches Pilzj. 4: 36. 1994.

[Flavoscypha phlebophora (Berk. \& Broome) Harmaja sensu Dennis (1978; P1. VIII D, not "E" as given)]

Deciduous grass-herb woods with Corylus, also an urban deciduous grove. Apparently calcicole. On more or less bare mull soil. Tolerates strong human influence. Hemiboreal. Very infrequent, southernmost Finland (V: Lohja and U: Helsinki).

Europe houses at least three very closely related Otidea taxa that share citrine outside and pale pinkish buff hymenium in fresh apothecia: $O$. concinna, O. integra (Bres.) Harmaja and $O$. subconcinna nom. prov. The differences between the two first-named are given in Harmaja (1986). $O$. subconcinna nom. prov. differs from $O$. integra: apothecia are usually split, spores are apparently slightly narrower (c. $5 \mu \mathrm{m}$ vs. $5-6 \mu \mathrm{m}$ wide), roughly half of paraphyses are curved (vs. most of them), paraphysis end cells are shorter on the average, and paraphysis tips are thinner $(2-5.5 \mu \mathrm{m}$ vs. up to $7.5 \mu \mathrm{m}$ thick). At times globose structures, $7-10 \mu \mathrm{m}$ in diam. and with brown walls, occur in tintricata. They may be endoconidia, resembling structures diagnostic of Peziza lohjaënsis Harmaja (Harmaja 1986).

The present taxon may well deserve the specific rank; it undoubtedly has additional occurrences in temperate and hemiboreal Europe but, like $O$. integra, apparently has mainly been included in the variability of $O$. concinna.

\section{O. tuomikoskii Harmaja}

Mesic heath forest and grass-herb forest. Possibly always with Picea. At times on hills or by paths of ants (Formica). May somewhat prefer 


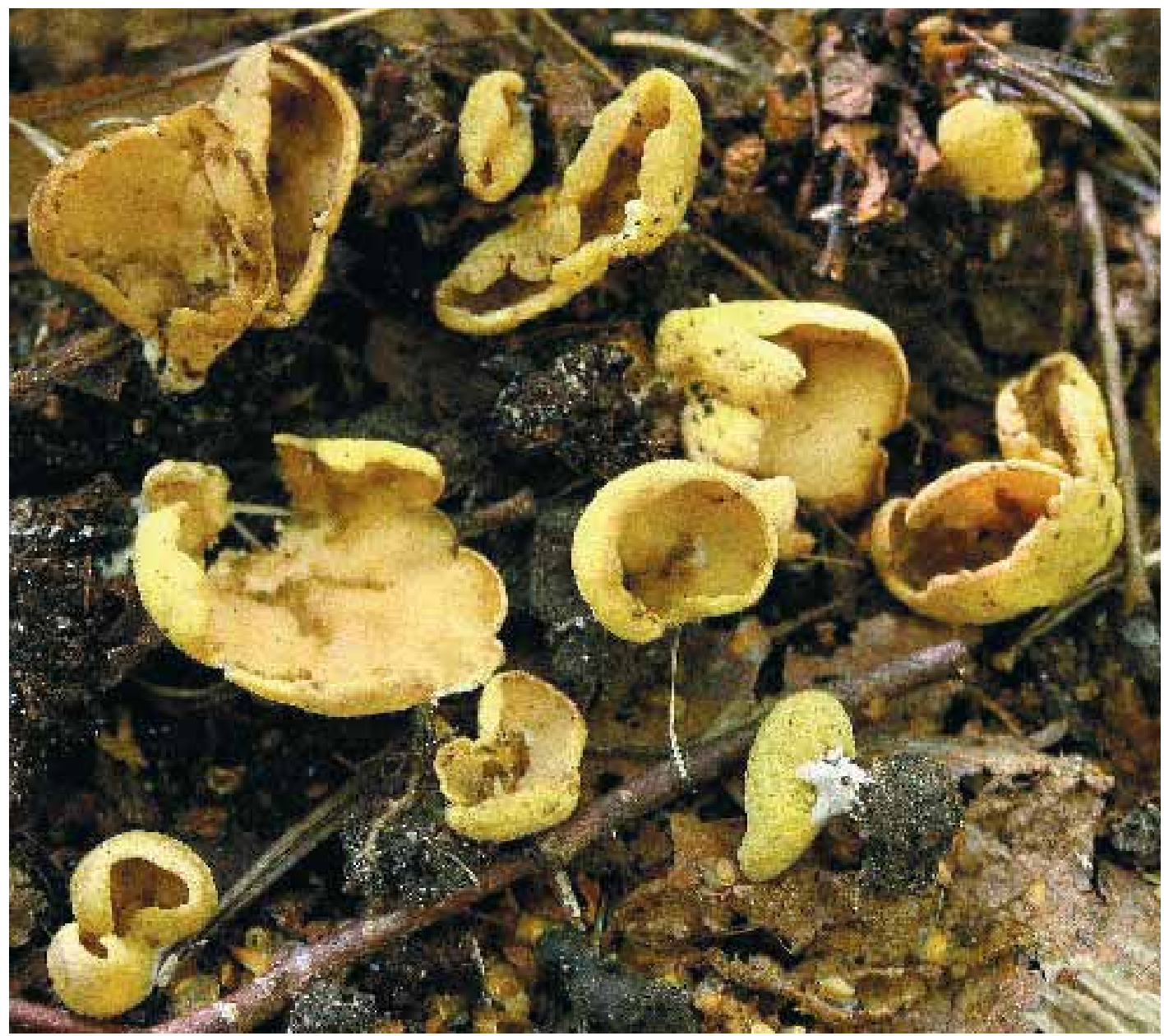

Fig. 4. Otidea subconcinna nom. prov., in situ, $\times 2.2$ (V, Lohja, Pähkinäniemi, 6680:3333, 12.IX.2006 U. Salo \& P. Salo 10724; H 6003841). - Photo: Pertti Salo.

old-growth forest. Somewhat prefers nutrientrich soils (has even been encountered on truly calcareous ground). In litter: mainly spruce needles, rarely on decaying wood. Hemiboreal to northern boreal. Most of Finland, apparently absent from Lapland. Uncommon.

Apparently widespread in the northern hemisphere. - For a good illustrated description $O$. tuomikoskii, see Van Vooren et al. (2008, including the cover of the journal issue).

\section{Notes on Otidea unicisa (Peck) Harmaja}

It was for a long time ago that Dr. Harold $\mathrm{H}$. Burdsall, Jr., now Professor emeritus, sent me material from North Carolina of what he had used to call Otidea grandis (Pers.) Rehm but was still hesitant as to the correctness of the identification. On my study, the material turned out to represent $O$. unicisa (Peck) Harmaja (Harmaja 1986). The species is new to North Carolina (the material was, due to some inexplicable reason, omitted in my 1986 paper).

The encrusted matter on the cell walls of the ectal excipulum is responsible for the reddish brown tinge of the external surface of the apothecia in Otidea unicisa. In boiled cotton blue mounts, the matter, crystalloid appearing pigment, melts into globose or irregular, yellowbrown drops with small paler inclusions. Similar phenomenon, as observed in some Finnish Oti- 
dea species in Melzer mounts, is described above in the section "Previously unreported responses of pigment encrustations to Melzer's reagent".

Despite my 1986 paper, Otidea unicisa still seems to be totally unknown in North America, though the species no doubt is widely distributed and not infrequent in the eastern half of the United States. The herbarium specimens that I then reported were mostly named as $O$. leporina or $O$. onotica. However, I later observed that the sharp-eyed mycologist, Professor Bessie B. Kanouse (1950) in a way recognized this species: she reported "the inner spore wall" to become minutely roughened in age. Actually, she partly cited same materials as I: a different specimen from the collection distributed as no. 1778 in Ellis \& Everhart: N. A. Fungi, $2^{\text {nd }}$ ser. Kanouse (1950) used the same, dubious and confused, name $O$. grandis as Professor Burdsall for this fungus. For a description of $O$. unicisa, see also Moravec (1994).

O. unicisa is unique in Otidea in that the secondary wall of the spores is not temporary but persistent, being delicately ornamented in mature spores (Harmaja 1986). Moravec (1994) considered this too deviating for an Otidea, and consequently removed the species from Otidea. He moved it to Sowerbyella Nannf. as S. unicisa (Peck) J.Moravec. However, O. unicisa, the present specimens included, has a split apothecium and excipular anatomy typical of Otidea but lacks e.g. the distinct stipe and the hairs of apothecial outside of Sowerbyella. I still consider the present species to belong to Otidea.

Specimens examined: U.S.A. North Carolina. Macon County. Near summit of Standing Indian Mt. On duff and buried wood of Betula, 1.VIII.1969 H. H. Burdsall, Jr. 2605 (H, 2 ex.; further duplicates, not studied by me, of the same collection are deposited in some herbaria at least in U.S.A.).

Acknowledgements: I am grateful to a number of colleagues and other people in Finland and abroad, some of them not being among us anymore, for collecting material of Otidea and for valuable discussions during a long elapse of time. Dr. Seppo Huhtinen (University of Turku) made improvements to the original version of the manuscript. Mr. Pertti Salo, M. Sc. (University of Helsinki), allowed me to publish a photograph of his. The main
Finnish herbaria (TUR, OULU, KUO) and Nationaal Herbarium Nederland (L) in the Netherlands sent material on loan. The biological stations of the University of Helsinki (in Lammi and Kilpisjärvi) and that of the University of Oulu (in Oulanka, Kuusamo) provided excellent working facilities for my field work.

\section{References}

Ahti, T., Hämet-Ahti, L. \& Jalas, J. 1968: Vegetation zones and their sections in northwestern Europe. Ann. Bot. Fennici 5: 169-211.

Breitenbach, J. \& Kränzlin, F. 1984: Fungi of Switzerland. Vol. 1 Ascomycetes. - 310 pp. Luzern.

Bresadola, J. 1933: Iconographia Mycologica. 25 + suppl. 5. - Pls. 1201-1250 + I-LX + 1-156. Mediolani.

Dennis, R. W. G. 1978: British Ascomycetes. $-2^{\text {nd }}$ ed. 585 pp. + pls. 1-44. Vaduz.

Franchi, P., L. Lami, L. \& M. Marchetti, M. 1999: Helvella leporina, nome corretto per Helvella silvicola. Rivista Micol. 42: 62-72.

Harmaja, H. 1974a: Flavoscypha, a new genus of the Pezizales for Otidea cantharella and O. phlebophora. Karstenia 14: 105-108.

Harmaja, H. 1974b: Observations on the presence of a cyanophilic perispore in the spores of the Pezizales. Karstenia 14: 123-125.

Harmaja, H. 1974c: The generic limit between Otidea and Tarzetta (Pustularia auct.). - Karstenia 14: 138-142.

Harmaja, H. 1976: New species and combinations in the genera Gyromitra, Helvella and Otidea. - Karstenia 15: 29-32.

Harmaja, H. 1986: Studies on the Pezizales. - Karstenia 26: 41-48.

Kanouse, B. 1950 ("1949"): Studies in the genus Otidea. - Mycologia 41: 660-677.

Korf, R. P. \& Zhuang, W.-Y. 1991: A preliminary Discomycete flora of Macaronesia: part 15, Terfeziaceae, and Otideaceae, Otideoideae. - Mycotaxon 40: 413433.

Maerz, A. \& Paul, M. R. 1950: A dictionary of color. 208 pp. New York.

Moravec, J. 1994: Some new taxa and combinations in the Pezizales. - Czech Mycol. 47: 261-269.

Nannfeldt, J. A. 1966: On Otidea caligata, O. indivisa and O. platyspora (Discomycetes Operculatae). - Ann. Bot. Fennici 3: 309-318.

Salo, P., Niemelä, T. \& Salo, U. 2006: Suomen sieniopas. -512 pp. Helsinki.

Van Vooren, N., Hairaud, M. \& Jindřich. O. 2008: Otidea tuomikoskii, Otidea papillata et Otidea papillata $f$. pallidefurfuracea $\mathrm{f}$. nov., trois taxons remarquables appartenant au genre Otidea (Pezizales, Pyronemataceae). - Bull. mycol. bot. Dauphiné-Savoie 48 (188): 47-57. 